\title{
F18 FDG PET/CT findings in cat-scratch disease: a case report
}

\section{Kedi tırmığı hastalığında F18 FDG PET/BT bulguları: olgu sunumu}

\author{
Neslihan Çetin $\mathrm{Avcl}^{1}$ (D) Mehmet Taha Avcı ${ }^{2}$ Aysegül $\mathrm{Akgün}^{3}$ (D) \\ ${ }^{1}$ Department of Nuclear Medicine, Umraniye Training and Research Hospital, Istanbul, Turkey \\ ${ }^{2}$ Department of Radiology, Umraniye Training and Research Hospital, Istanbul, Turkey \\ ${ }^{3}$ Department of Nuclear Medicine, Ege University, Izmir, Turkey
}

\begin{abstract}
Cat-scratch disease is a bacterial infection caused by Bartonella Henselae which affects lymph nodes that drain the sites of inoculation. Axillary, cervical and inguinal lymph nodes are the most common regions being involved. The disease can be considered as an FDG-avid disease, given the granulomatous nature of the infection. We herein report F18 FDG PET/CT findings of a 49-year-old woman, who has abdominal lymphadenopathy revealed on ultrasonography (USG). PET/CT scan demonstrated bilateral axillary and abdominopelvic hypermetabolic enlarged lymph nodes with SUVmax value of 6.2 to 18.5. Moreover, a hypermetabolic hypodense lesion in the spleen with SUVmax value of 11.3 was detected. Excisional biopsy of the axillary lymph node performed. Based on clinical-histopathological findings and the history of being scratched by a cat recently, the patient was diagnosed with cat-scratch disease. In conclusion, cat-scratch disease represents a cause of false-positive results in oncological PET/CT scans. Furthermore, PET/CT may have a role in revealing the applicable biopsy area and showing the additional involvement sites.
\end{abstract}

Keywords: Cat-Scratch Disease, PET-CT, Lymphadenopathy.

\section{ÖZ}

Kedi tırmığı hastalığı, Bartonella Henselae isimli bakterinin neden olduğu ve inokülasyon sahasını direne eden lenf nodlarının etkilendiği bir enfeksiyondur. Kedi tırmığı hastalığında en sık olarak aksiller, servikal ve inguinal yerleşimli lenf nodları etkilenmektedir. Doğasındaki granulomatozis nedeni ile bu hastalık FDG-avid kabul edilebilir. Ultrasonografik incelemesinde multipl abdominal lenfadenopati saptanan 49 yaşındaki kadın olgunun FDG-PET/BT bulgularını sunmaktayız. Olgunun F18 FDG PET/BT tetkikinde, bilateral aksiller ve abdominopelvik yerleşimli hipermetabolik lenf nodları yanısıra (SUVmax:6.2-18.5), dalakta hipermetabolik hipodens bir lezyon saptandı (SUVmax:11.3). Uygulanan aksiller lenf nodu eksizyonu sonrası patolojik olarak süpüratif gralülomatöz lenfadenit saptanmasına, yakın zamanda kedi tırmalaması öyküsünün eşlik ediyor oluşu ile, olguya Kedi Tırmığı Hastalığı tanısı konuldu. Sonuç olarak onkolojik PET/BT tetkikinde yalancı pozitiflik sebepleri arasında Kedi tırmığı hastalığı da akılda tutulmalıdır. Ek olarak, Kedi tırmığı hastalığında PET/BT'nin uygun biyopsi alanını göstermede ve diğer hastalık alanlarının saptanmasında rol oynayabileceği düşünülmektedir.

Anahtar Sözcükler: Kedi tırmığı hastalığı, PET/BT, Lenfadenopati.

\section{INTRODUCTION}

Cat-scratch disease (CSD) is a bacterial infection caused by Bartonella Henselae. Lymph nodes that drain sites of cutaneous inoculation are mainly affected in the spectrum of the disease (1). Despite the fact that most of the patients may remember the history of being scratched, licked or bitten by a domestic cat before the symptom manifestation, infection with $B$.
Corresponding author: Neslihan Çetin Avcı

Department of Nuclear Medicine, Umraniye Training and

Research Hospital, Istanbul, Turkey

E-mail: nanoin@hotmail.com

Application date: 01.06.2020
Accepted: 08.09.2020 


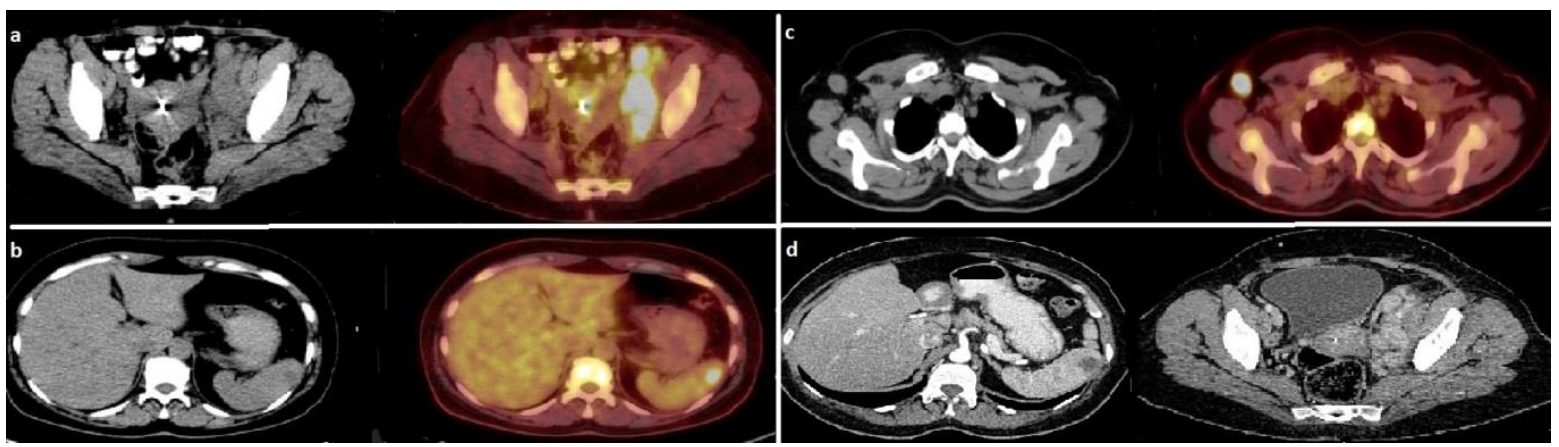

Figure-1. FDG PET/CT, non-enhanced CT and fusion images: (a) multiple enlarged hypermetabolic pelvic lymph nodes, (b) a hypodense, hypermetabolic splenic lesion, (c) right axillary hypermetabolic enlarged lymph node was the most appropriate area for biopsy, (d) contrast-enhanced CT, portal venous phase: a hypodense splenic lesion and multiple enlarged pelvic lymph nodes ( 2 mounts after treatment).

Henselae can be transmitted by arthropod vectors as well. Therefore, the history of animal contact is not necessary for disease transmission (2).

CSD is presented with regional lymphadenopathy, fever, fatigue, and weakness. Axillary, cervical, and inguinal lymph nodes are the most common regions being affected in CSD (3).

Visceral organ, ocular and neurologic involvement may occur (4). Given the granulomatous nature of the infection, it may be considered as an FDG-avid disease $(5,6)$. In this report we are presenting a case of systemic CSD with F18 fluoro-deoxy-glucose (FDG) positron emission tomography/computed tomography (PET/CT) findings.

\section{Case Presentation}

A 49-year-old woman with abdominal lymphadenopathy with the differential diagnosis of lymphoma or malignancy of unknown origin was referred to our clinic for FDG PET/CT scan.

$\mathrm{PET} / \mathrm{CT}$ (Biograph high-definition 16-slice CT, Siemens Healthcare, Erlangen, Germany) scan demonstrated bilateral axillary and abdominopelvic hypermetabolic lymphadenopathy with SUVmax value of 6.2 to 18.5 (Figure-1a). Besides, there was a hypermetabolic hypodense splenic lesion in the size of $1.4 \times 1.2 \mathrm{~cm}$ with SUVmax value of 11.3 (Figure-1b). It is pointed out that the right axillary lymph node in the size of $1.9 \times 2.5 \mathrm{~cm}$ with SUVmax value of 16.2 is suitable for biopsy, in the scan report (Figure-1c). Excisional biopsy of the suggested lymph node performed. Results were compatible with suppurative granulomatous lymphadenitis. Based on clinical-histopathological findings and the history of being scratched by a cat recently, the patient was diagnosed with cat scratch disease.

2 mounts after antibiotic treatment, abdominal contrast-enhanced CT was performed. CT revealed an ill-defined hypodense lesion in the lateral part of the upper pole of the spleen, without significant enhancement neither in the arterial nor the portal venous phase images. Compared to the PET/CT scan, the lesion had increased in size (measured $2 \times 1.9 \mathrm{~cm}$ ). Abdominopelvic lymph nodes showed partial anatomic regression (Figure-1d). But there was a left inguinal lymph node measured $2.0 \times 2.4 \mathrm{~cm}$, with central necrosis, as a new finding. Thus, all these findings despite antibiotics, raised suspicion for malignancy again. Biopsy of omentum and excision of retroperitoneal lymph nodes was performed. The histopathological report was consistent with the previous one, denoting suppurative granulomatous lymphadenitis, reminding of CSD. In addition, bone marrow aspiration showed normocellular marrow.

\section{DISCUSSION}

Cat-scratch disease is a bacterial infectious disease that is usually characterized by selflimited febrile illness with regional lymphadenopathy. However, the disease spectrum can include visceral organs, neurologic, and ocular involvement $(1,4)$.

The key to the diagnosis relies on the suspicion of CSD. When the clinical manifestations are typical of CSD, some experts suggest it is adequate for diagnosis. But laboratory investigation (serological tests) is needed to confirm the diagnosis. When it is not enough, nonspecific findings of granulomas in the tissue specimens can support the diagnosis $(4,7)$. 
It's well known that activated inflammatory cells (lymphocytes, macrophages, granulocytes, etc.) have increased number of glucose transporter (GLUT 1) and enhanced glycolysis. Thus, granulomatous disorders like tuberculosis, sarcoidosis, cat scratch disease and fungal infections show increased FDG uptake since granulomas histologically consist of mononuclear inflammatory cells or macrophages surrounded by lymphocytes. $(8,9)$.

In the spectrum of CSD, involvement of spleen may be seen as of other visceral organs. Features of the involvement are round, welldefined hypoechoic lesions in USG and also welldefined low-attenuated lesions CT (10). In our case, there was a hypodense lesion in the spleen, in addition to lymphadenopathy. Moreover, all disease sites showed increased FDG uptake concordant with the literature $(11,12)$.

\section{CONCLUSION}

Cat-scratch disease represents a cause of falsepositive results in oncological FDG PET/CT scans. PET/CT has no primary role in the diagnose of CSD, and also it may bring up reimbursement issues. Serological evaluation of the blood is adequate in most of the cases. On the other hand, it can be challenging to consider CSD in the first line of differential diagnoses when there is extra nodal involvement. Malignancies with metastasis, lymphoma or other systematic infectious diseases are more likely the cause. Nonetheless, PET/CT may be useful revealing the most appropriate site for biopsy and showing additional involvement sites as well.

\section{Acknowledgements}

The authors declare no conflict of interest.

\section{References}

1. Bergman AM, Groothedde JW, Schellekens JFP, van Embden JD, Ossewaarde JM, Schouls LM. Etiology of catscratch disease: a comparison of polymerase chain reaction detection of Bartonella and Afipia felis DNA with serology and skin tests. J Infect Dis. 1995; 171 (4): 916-23.

2. Mosbacher ME, Klotz S, Klotz J, Pinnas JL. Bartonella henselae and the potential for arthropod vector-borne transmission. Vector Borne Zoonotic Dis. May 2011; 11 (5): 471-7.

3. Markaki S, Sotiropoulou M, Papaspirou P, Lazaris D. Cat-scratch disease presenting as a solitary tumour in the breast: report of three cases. Eur J Obstet Gynecol Reprod Biol. 2003; 106 (2): 175-8.

4. Spach DH, Kaplan SL. Microbiology, epidemiology, clinical manifestations, and diagnosis of cat scratch disease. In: UpToDate, Post TW (Ed), UpToDate, Waltham, MA. (Accessed on May 28, 2020).

5. Vaidyanathan S, Patel CN, Scarsbrook AF, Chowdhury FU. FDG PET/CT in infection and inflammation-current and emerging clinical applications. Clin Radiol. 2015; 70 (7): 787-800.

6. Asano S. Granulomatous lymphadenitis. J Clin Exp Hematop 2012; 52 (1): 1-16.

7. Sander A, Berner R, Ruess M. Serodiagnosis of cat scratch disease; response to Bartonella henselae in children and review of diagnostic methods. Eur J Clin Microbiol Infect Dis. 2001; 20 (6): 392-401.

8. Lin E, Alavi A. PET and PET/CT A clinical guide, Second edition. Thieme Medical Publishers, Inc.2009. P:25.

9. Nwawka OK, Nadgir R, Fujita A, Sakai O. Granulomatous disease in the head and neck: developing a differential diagnosis. Radiographics. 2014; 34 (5): 1240-56.

10. Rappaport DC, Cumming WA, Ros PR. Disseminated hepatic and splenic lesions in cat-scratch disease: imaging features. AJR Am J Roentgenol. 1991; 156 (6): 1227-8.

11.Jeong W, Seiter K, Strauchen J. et al. PET scan-positive cat scratch disease in a patient with $\mathrm{T}$ cell lymphoblastic lymphoma. Leuk Res. 2005; 29 (5): 591-4.

12. Imperiale A, Blondet C, Ben-Sellem D. Et al. Unusual Abdominal Localization of Cat Scratch Disease Mimicking Malignancy on F-18 FDG PET/CT Examination. Clin Nucl Med 2008; 33 (9): 621-3. 